\title{
Penumbra salvage and infarct growth in acute ischemic stroke: Multiple factors explain high interindividual variability
}

\author{
G Sirimarco, MD, PhD1, D Strambo, MD¹, S Nannoni, MD1, C Cereda, MD ${ }^{1,2}, \mathrm{~J}$ Labreuche, BS ${ }^{3}, \mathrm{G} \mathrm{Saliou,} \mathrm{MD,} \mathrm{PhD}{ }^{4}$, \\ R Meuli, MD ${ }^{4}, A$ Eskandari, RN1, M Wintermark, MD ${ }^{4,5}, \mathrm{P}^{1}$ Michel, MD ${ }^{1}$ \\ 1 Neurology Service and ${ }^{4}$ Department of Diagnostic and Interventional Radiology of the Lausanne University Hospital, Lausanne, Switzerland \\ 2Stroke Center, Neurology Service, Ospedale Civico di Lugano, Lugano, Switzerland \\ ${ }^{3}$ Department of Biostatistics, EA 2694-Santé publique : épidémiologie et qualité des soins, Univ. Lille, France \\ ${ }^{5}$ Department of Diagnostic and Interventional Radiology of Neuroradiology Division, Stanford University and Medical Center, Stanford, USA
}

\section{Background and aims}

Effective treatment of ischemic stroke requires reperfusion of the penumbral brain tissue.

We aimed at investigating predictors of penumbra salvage and infarct growth.

\section{Methods}

In the Acute STroke Registry and Analysis of Lausanne (ASTRAL) from 2003 to 2016, we selected all middle cerebral artery (MCA) strokes with availability of a good quality CT-angiography $<24 \mathrm{~h}$ and thresholded CT-perfusion.

Penumbra salvage (PS) and infarct growth (IG) over 24 hours were correlated in multivariate analyses with clinical, radiological and biochemical variables, and in adjusted analysis with clinical outcome.

\section{Results}

In the 551 MCA strokes included, $49.2 \%$ were females, median age ( \pm IQR) was $68.7 \pm 21$, admission NIHSS $14 \pm 12$, and onset-to-imaging time $169.5 \pm 283$ minutes.

More PS was associated with higher BMI, hemineglect, absence of early ischemic changes, leukoaraiosis, other vascular territory involvement, larger baseline penumbra and a lower clot burden. Less IG was associated with current smoking, lower admission glycemia, larger baseline infarct core, absence of early ischemic changes, chronic vascular brain lesions, other territory involvement, absence of extracranial arterial pathology and hyperdense MCA sign, and lower clot burden. Adding subacute variables to these analyses, recanalisation were associated with more PS and less $I G$, and the absence of parenchymal haemorrhage with less IG (Table 1,2).

More PS and less IG were independently correlated with better 3 and 12 months functional outcome.

\begin{tabular}{|c|c|c|}
\hline \multirow[t]{2}{*}{ Independent predictors of penumbra salvage } & \multicolumn{2}{|c|}{ Acute and subacute model } \\
\hline & $\mathrm{OR}(95 \% \mathrm{CI})^{1}$ & P Value \\
\hline \multicolumn{3}{|l|}{ Acute variables } \\
\hline Baseline penumbra (per $1 \log$ SD increase) & $18.05(11.90$ to 27.36$)$ & $<0.001$ \\
\hline Leukoaraiosis & $0.46(0.27$ to 0.77$)$ & 0.003 \\
\hline PCA and/or ACA involved & $0.36(0.17$ to 0.77$)$ & 0.008 \\
\hline Neglect & 1.66 (1.11 to 2.49$)$ & 0.013 \\
\hline Early ischemic changes & $0.56(0.36$ to 0.85$)$ & 0.006 \\
\hline Clot burden score (per 1 point increase) & $1.13(1.04$ to 1.22$)$ & 0.003 \\
\hline BMI (per 1 SD increase) & 1.31 (1.04 to 1.65$)$ & 0.020 \\
\hline WBC (per $1 \log$ SD increase) & $0.82(0.66$ to 1.01$)$ & 0.056 \\
\hline \multicolumn{3}{|l|}{ Subacute variables } \\
\hline Recanalisation & & $0.006^{2}$ \\
\hline No occlusion & 1.00 (reference) & - \\
\hline Recanalized & 2.34 (1.27 to 4.29$)$ & 0.006 \\
\hline Non-recanalized & 1.28 (0.64 to 2.56$)$ & 0.48 \\
\hline Parenchymal hemorrhage at $24 \mathrm{~h}$ & 0.56 (0.29 to 1.07$)$ & 0.078 \\
\hline \multicolumn{3}{|c|}{$\begin{array}{l}\text { Table 1. Independent predictors of penumbra salvage (categorized into } \\
\text { tertiles). } 1 \text { Common odds ratio for higher tertiles in volume change of } \\
\text { penumbra; } 2 \mathrm{P} \text {-value for overall effect. Model } 2 \text { calculated using a backward- } \\
\text { stepwise ordinal logistic model including all univariate acute and subacute } \\
\text { predictors at } P<0.10 \text {. }\end{array}$} \\
\hline
\end{tabular}

\begin{tabular}{|l|c|c|}
\hline Independent predictors of infarct growth & \multicolumn{2}{|c|}{ Acute and subacute model } \\
\hline & OR (95\%CI) ${ }^{1}$ & P Value \\
\hline Acute variables & & \\
\hline Baseline infarct core (per 1 log SD increase) & $0.44(0.34$ to 0.55$)$ & $<0.001$ \\
\hline Early ischemic changes & $2.27(1.55$ to 3.31$)$ & $<0.001$ \\
\hline PCA and/or ACA involved & $5.76(2.75$ to 12.05$)$ & $<0.001$ \\
\hline Blood glucose (per 1 log SD increase) & $1.33(1.11$ to 1.59$)$ & 0.002 \\
\hline Leukoaraiosis & $2.05(1.30$ to 3.23$)$ & 0.002 \\
\hline Hyperdense MCA & $1.91(1.22$ to 2.98$)$ & 0.004 \\
\hline Extracranial stenosis $\geq 50 \%$ or occlusion & $1.55(1.03$ to 2.30$)$ & 0.032 \\
\hline Clot burden score (per 1 point increase) & $0.87(0.80$ to 0.95$)$ & 0.001 \\
\hline Current smoking & $1.54(1.05$ to 2.25$)$ & 0.027 \\
\hline Old infarct & $1.66(1.11$ to 2.51$)$ & 0.015 \\
\hline Good Collaterals & Not selected & - \\
\hline Subacute variables & & \\
\hline Recanalisation & & $<0.0012$ \\
\hline No occlusion & 1.00 (reference) & - \\
\hline Recanalized & $0.50(0.31$ to 0.83) & 0.006 \\
\hline Non-recanalized & 1.11 (0.64 to 1.90) & 0.72 \\
\hline Parenchymal hemorrhage at 24h & 2.61 (1.39 to 4.87$)$ & 0.003 \\
\hline
\end{tabular}

Table 2. Independent predictors of infarct growth (into tertiles). 1 Common odds atio for higher tertiles in change of Infarct core; 2 P-value for overall effect. Model 2 calculated using a backward-stepwise ordinal logistic model including all univariate acute and subacute predictors at $\mathrm{P}<0.10$.

\section{Conclusion}

Penumbra salvage and infarct growth depend on multiple clinical, metabolic, parenchymal, and arterial variables. These findings may explain variability of treatment response and outcome, and may help select patients for late or more aggressive management. 